\title{
Toxicity of Zinc Dissolved In Saigon River to the Tropical Micro-Crustacean Daphnia Lumholtzi
}

\author{
Thanh-Son Dao (corresponding author) \\ Hochiminh City University of Technology, Vietnam National University-Hochiminh City \\ 268 Ly Thuong Kiet Street, District 10, Hochiminh City, Vietnam \\ Tel: 84-838-639-682 E-mail: dao.son@hcmut.edu.vn \\ Le-Thanh-Tuyen Tran \\ Institute for Environment and Resources, Vietnam National University-Hochiminh City \\ 142 To Hien Thanh Street, District 10, Hochiminh City, Vietnam \\ Tel: 84-838-651-132Ｅ-mail: tranthanhtuyen2309@gmail.com \\ Thi-My-Chi Vo \\ Hochiminh City University of Technology, Vietnam National University-Hochiminh City \\ 268 Ly Thuong Kiet Street, District 10, Hochiminh City, Vietnam \\ Tel: 84-838-639-682Ｅ-mail: vtmchi@hcmut.edu.vn

\begin{abstract}
Ba-Trung Bui
Institute for Environment and Resources, Vietnam National University-Hochiminh City, 142 To Hien Thanh Street, District 10, Hochiminh City, Vietnam

Tel: 84-838-651-132Ｅ-mail: redtidenhatrang@gmail.com
\end{abstract}

Received: August 13, 2016 Accepted: August 26, 2016

doi:10.5296/emsd.v5i2.9999 URL: http://dx.doi.org/10.5296/emsd.v5i2.9999

\begin{abstract}
In this study we evaluated the responses of the tropical micro-crustacean, Daphnia lumholtzi,
\end{abstract}


to zinc ( $\mathrm{Zn}$ ). For a more environmentally realistic assessment on the $\mathrm{Zn}$ toxicity, water sample collected from Saigon River was used as medium for the daphnids and $\mathrm{Zn}$ was spiked into field water for exposures. River water was physically and chemically measured and analyzed, and the sufficient water quality was confirmed prior to be used for the acute and chronic experiments. Metal concentrations in the test water were determined with an inductively coupled plasma/ mass spectrometry (ICP/MS). In the acute test implementation, $\mathrm{Zn}$ concentrations were from $67-360 \mu \mathrm{g} / \mathrm{L}$. In the chronic experiments, the animals were incubated in control (filtered field water only) or filtered field water added with $\mathrm{Zn}$ (28, 46, and $75 \mu \mathrm{g} / \mathrm{L}$ ) over the period of 14 days. The life history traits of daphnids including the survival, maturation, reproduction were daily observed. The results showed that the value of median lethal concentrations (48h-LC ${ }_{50}$ ) was $136 \mu \mathrm{g} \mathrm{Zn/L} \mathrm{(95 \%} \mathrm{CI} \mathrm{=} 107-165 \mu \mathrm{g} \mathrm{Zn/L).}$ Chronic exposures revealed that $\mathrm{Zn}$ caused the survival reduction, delayed maturity age and reproduction decrease. Our study suggested $D$. lumholtzi as a very good freshwater aquatic zooplankton for assessment on the toxicity of metals in tropics. Besides, the Vietnam guideline values regarding $\mathrm{Zn}$ should be re-considered and adjusted for the aquatic ecological protection.

Keywords: Acute toxicity, Chronic effects, Daphnia lumholtzi, Saigon River water, Zinc

\section{Introduction}

Trace metals are part of natural characteristics of aquatic and terrestrial environment. However, anthropogenic emissions (e.g. industrial and agricultural activities) have led to the metal concentration increase in aquatic environment. Metals are among the most common aquatic pollutants which are difficult to control (Tomasik and Warren, 1996). In aquatic ecosystem, many heavy metals such as zinc $(\mathrm{Zn})$, copper $(\mathrm{Cu})$, and nickel $(\mathrm{Ni})$ among others at low concentrations are very important and essential for aquatic organisms (Wetzel, 2001). Nevertheless, these metals, at high concentrations, could intoxicate organisms such as phytoplankton, zooplankton and fish. In aquatic ecosystem, zooplanktons play a very important trophic position in the food chain and food web. Cladocerans, a group of zooplankton, consist of many genera and species (e.g. Daphnia) which are very sensitive to pollutants and widely used as good models for aquatic toxicological studies (Lampert, 2006; Shaw et al., 2008).

Numerous investigations on the toxicity of metals (e.g. $\mathrm{Zn}, \mathrm{Cd}, \mathrm{Ni}, \mathrm{Pb}$ ) on micro-crustaceans have been investigated. Naddy et al. (2015) conducted the acute test of $\mathrm{Zn}$ dissolved in artificial medium with the micro-crustacean Ceriodaphnia dubia and reported the 48h-LC 50 values of $61.8-130 \mu \mathrm{g} / \mathrm{L}$. Vardia et al. (1998) and Chishty et al. (2012) reported the $48 \mathrm{~h}-\mathrm{LC}_{50}$ values of $D$. lumholtzi tested with $\mathrm{Zn}$ dissolved in tap water were 2290 and 2300 $\mu \mathrm{g} / \mathrm{L}$, respectively. The median effective (immobilized) concentration $\left(48 \mathrm{~h}-\mathrm{EC}_{50}\right)$ values of four different metals $(\mathrm{Cd}, \mathrm{Cu}, \mathrm{Ni}, \mathrm{Zn})$ to Daphnia magna were much different and the toxicity order of those metals to the tested species was $\mathrm{Cd}>\mathrm{Cu}>\mathrm{Zn}>\mathrm{Ni}$ (Traudt et al., 2016). Besides, $\mathrm{Cu}$ was more toxic than some other metals such as $\mathrm{Ni}, \mathrm{Zn}$ and chromium (Cr) to the two cladocerans, Moina macropora and D. magna (Biesinger and Christensen, 1972; Wong, 1992). Recently, Dao et al. (2016) reported the $48 \mathrm{~h}-\mathrm{LC}_{50}$ of D. lumholtzi exposed to 
Zn spiked into Mekong River water of 179.3 - $280.9 \mu \mathrm{g} / \mathrm{L}$. In chronic toxicity of metals to micro-crustaceans, there have been more investigations on the effects of $\mathrm{Cu}$ and $\mathrm{Ni}$ than $\mathrm{Zn}$. However, most previous studies agreed that the metals negatively affected on survivorship, maturity age and reproduction of micro-crustaceans (Winner and Farrell, 1976; Munzinger, 1994; Pane et al., 2004). Muyssen et al. (2006) recorded the negative impacts of Zn (340 $\mu \mathrm{g} / \mathrm{L}$ ) on survival of D. magna. Dao et al. (2016) reported the $\mathrm{Zn}$ dissolved in Mekong River water at the concentrations of $50-56 \mu \mathrm{g} / \mathrm{L}$ impaired the life history traits of $D$. lumholtzi such as survival, maturity age, growth, fecundity and reproduction. Generally, toxicity of metals to Daphnia was studied considerably with species from temperate regions such as Europe and North American (e.g. D. magna, D. pulex, D. parvula, D. ambigua). However, investigations on the toxicity, especially chronic effects, of dissolved metals in field waters to the tropical micro-crustacean D. lumholtzi remained limited (Dao et al., 2016).

Toxicity of dissolved metals to micro-crustacean is regulated by the test conditions (De Schamphelaere and Janssen, 2002; Jo et al., 2010). The increase of pH and humic acid concentration in the test medium led to the decrease of toxicity of $\mathrm{Zn}$ to D. magna (Paulauskis and Winner, 1988). Naddy et al. (2015) reported a large variation on the values of $48 \mathrm{~h}-\mathrm{LC}_{50}$ of $C$. dubia testing with $\mathrm{Cd}, \mathrm{Cu}$ and $\mathrm{Zn}$, under different hardness of the test medium. Similarly, dissolved metals (e.g. $\mathrm{Cu}, \mathrm{Ni}$ ) became more toxic when the hardness of water decreased (Taylor et al., 2016). Food availability also altered on the response of daphnids to metals and the fed daphnids got a higher tolerance to $\mathrm{Cu}$ than unfed daphnids (Dave, 1984).

Running through Hochiminh City Saigon River has largely contributed for the livelihood of so many local residents. Surface water from this river has been used as drinking water supply (Do-Hong et al., 2000). During the last decade, the rapid development of industrial activities up stream and along the Saigon River increases the threat to the water quality degradation of the river such metal contamination (Chanpiwat and Sthiannopkao, 2014). Consequently, environmental risks with metals in water of down stream Saigon River would be evoked. Hence, we questioned the potential toxicity affects on tropical micro-crustaceans in the near future. Also, we supposed that using field water for the toxicity tests would contribute a more realistic assessment of potential effects of metals than using artificial media (Dao et al., 2016). The aim of this study was to evaluate the acute and chronic effects of Zn spiked into Saigon River water on the tropical micro-crustacean, Daphnia lumholtzi.

\section{Materials and Methods}

\subsection{Water Sampling}

In September 2015, field water was collected at surface from Saigon River (Fig. 1). Water sample for toxicity tests were brought to the laboratory in the same day and prepared for the experiments. Field water was passed through the $0.45 \mu \mathrm{m}$ filter (Sartorius, Germany), stored in plastic containers prior to the experiments. Sub-sample from the sampling site was taken for analyses of dissolved metal, alkalinity and hardness. 


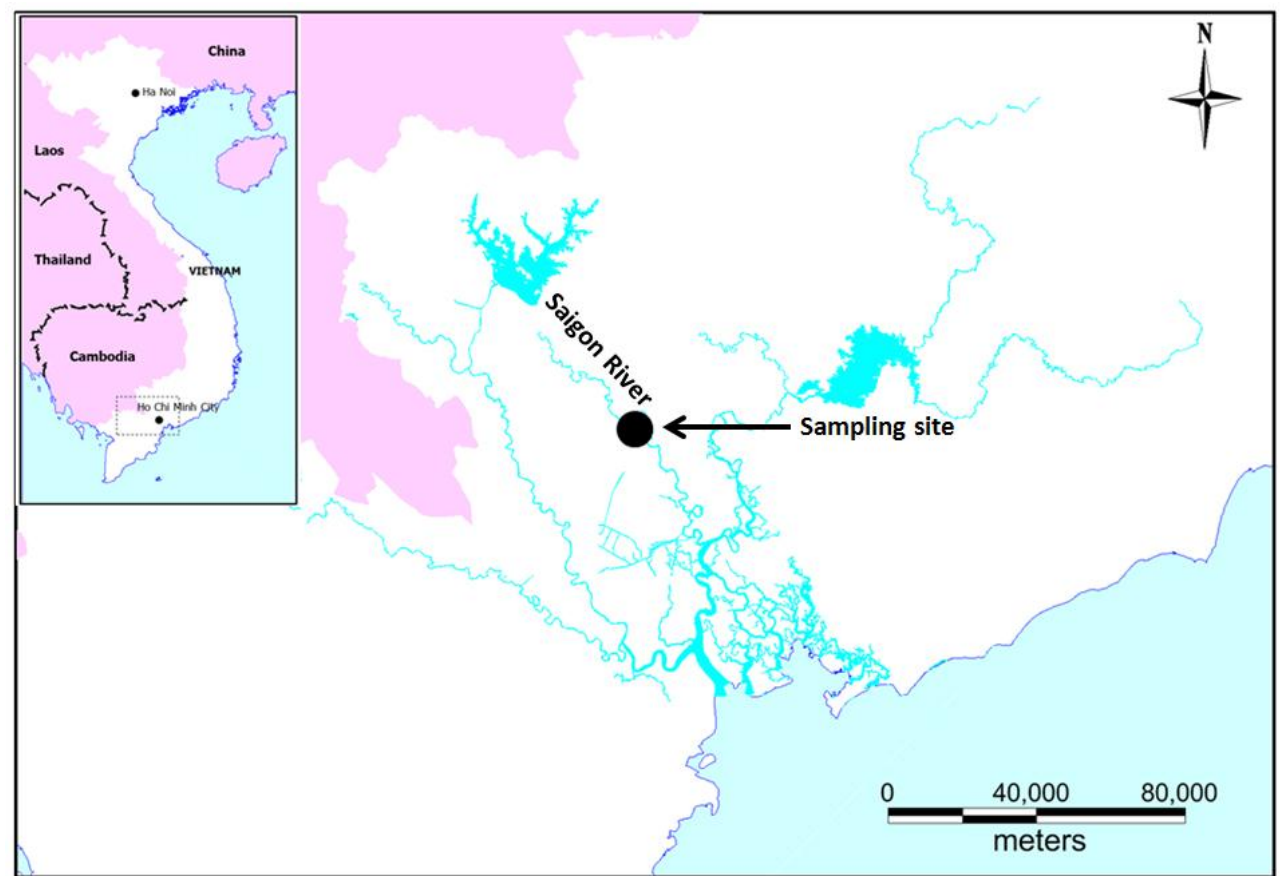

Figure 1. Saigon river in Vietnam with the sampling site, black round dot (coordinated with $10^{\circ} 58^{\prime} 31.2^{\prime \prime} \mathrm{N}$ and $\left.106^{\circ} 39^{\prime} 19.0^{\prime} \mathrm{E}\right)$, for the toxicity test.

\subsection{Physical and Chemical Characterization of the Field Water Sample}

The filtered water sample was acidified with concentrated $\mathrm{HNO}_{3}(65 \%$, Merck) and used for dissolved metal characterization (APHA, 2005) with an inductively coupled plasma/ mass spectrometry (ICP/MS - Agilent 7500, USA). All the interested metals in water samples were analyzed. The ICP-MS operating conditions and parameters for metal analysis in sample are presented in Table 1. For analysis, calibration solutions were analyzed followed by an initial calibration blank to control carry-over. Immediately following the initial calibration blank, an initial calibration verification which was prepared from a different source of analyses, was analyzed. The calibration verification standard should be a mid-range calibration standard. The percent recovery of the initial calibration verification standard should be $90-110 \%$ for each element being determined.

Table 1. ICP-MS operating conditions and parameters for metal analysis

\begin{tabular}{|l|l|}
\hline Operating conditions & \\
\hline Spray chamber & Scott double pass \\
\hline Nebulizer pump (rps) & 0.1 \\
\hline RF power $(\mathrm{W})$ & 1550 \\
\hline RF Matching $(\mathrm{V})$ & 0.2 \\
\hline Sample depth $(\mathrm{mm})$ & 8 \\
\hline Torch-H $(\mathrm{mm})$ & 0.2 \\
\hline Torch-V $(\mathrm{mm})$ & 0.2 \\
\hline Plasma gas flow rate $(\mathrm{L} / \mathrm{min})$ & 15 \\
\hline
\end{tabular}




\begin{tabular}{|l|l|}
\hline Carrier gas (Ar) flow rate & 0.9 (optimized daily) \\
\hline Measurement parameters & \\
\hline Scanning mode & Peak hopping \\
\hline Resolution (amu) & 0.7 \\
\hline Readings/replicate & 1 \\
\hline No. of replicates & 3 \\
\hline Internal standard & ${ }^{45} \mathrm{Sc}$ \\
\hline Isotopes - Collision gas $(\mathrm{He})$ & ${ }^{27} \mathrm{Al},{ }^{52} \mathrm{Cr},{ }^{55} \mathrm{Mn},{ }^{56} \mathrm{Fe},{ }^{59} \mathrm{Co},{ }^{60} \mathrm{Ni},{ }^{63} \mathrm{Cu},{ }^{66} \mathrm{Zn}^{75} \mathrm{As},{ }^{78} \mathrm{Se},{ }^{95} \mathrm{Mo}$. \\
\hline Isotopes - No gas & ${ }^{107} \mathrm{Ag},{ }^{111} \mathrm{Cd},{ }^{137} \mathrm{Ba},{ }^{208} \mathrm{~Pb}$. \\
\hline
\end{tabular}

The total hardness of filtered river water was determined based on concentrations of $\mathrm{Ca}^{2+}$ and $\mathrm{Mg}^{2+}$ and the alkalinity was determined by titration method (APHA, 2005).

\subsection{Toxicity Test}

The test micro-crustacean, Daphnia lumholtzi (Fig. 2), was collected from a fish pond in Northern Vietnam (Bui et al., 2016) and has been well maintained in the Laboratory of Environmental Toxicology, Institute for Environment and Resources, Vietnam National University - Hochiminh City, for more than 2 year. Daphnia lumholtzi was raised in COMBO medium (Kilham et al., 1998), at $27 \pm 1{ }^{\circ} \mathrm{C}$ with a photoperiod of $12 \mathrm{~h}$ light and $12 \mathrm{~h}$ dark and under the light intensity of around 1000 Lux. The micro-crustacean was fed with a mixture of green alga (Chlorella sp.) which was cultured in COMBO medium and YCT (yeast, cerrophyl and trout chow digestion), prepared according to the U.S. Environmental Protection Agency Method (US EPA, 2002).

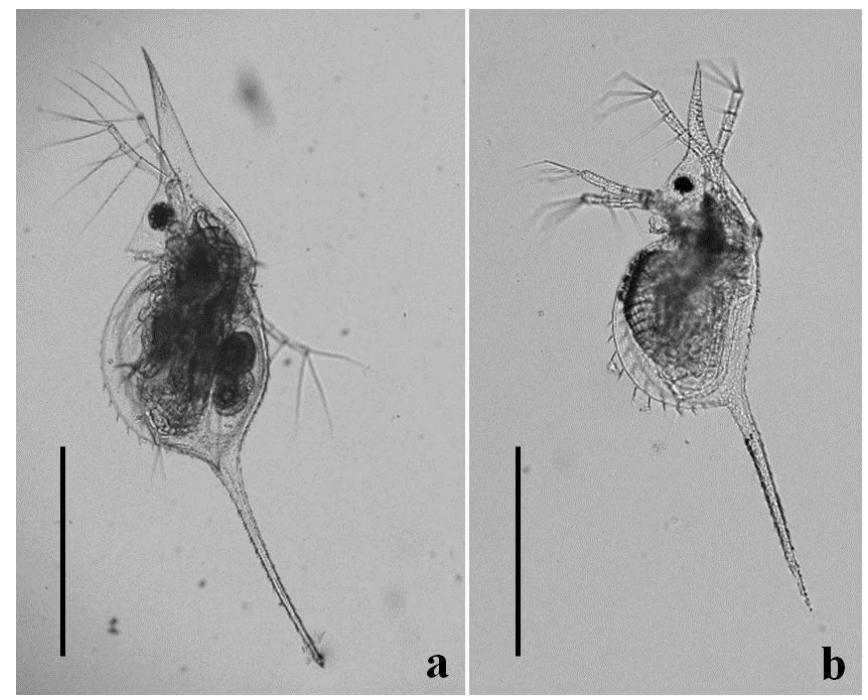

Figure 2. Daphnia lumholtzi from Vietnam; a, adult D. lumholtzi at its maturity age (scale bar $=500 \mu \mathrm{m})$ and b, new born $D$. lumholtzi $($ scale bar $=200 \mu \mathrm{m})$.

For control experiments, $D$. lumholtzi was incubated in the filtered field water while metal treatments were implemented by spiking Zn (stock solution of $1000 \mathrm{ppm}$, Merck) into the filtered field water prior to the test initiation.

The 48-h static nonrenewal acute toxicity tests were conducted according to the US EPA 
methods (US EPA, 2002) with a minor modification to temperature and light and temperature conditions for tropical species as mentioned above. The neonates of D. lumholtzi (age $\leq 24 \mathrm{~h}$ ) were used for testing. Organisms were fed before exposure but starved during the tests (US EPA, 2002). Each test included a control (field-collected water) and five treatment concentrations of $\mathrm{Zn}(67,113,179,309$, and $360 \mu \mathrm{g} / \mathrm{L})$. Four replicates per treatment with 10 organisms per replicate were used and the organisms were incubated in $50 \mathrm{~mL}$ polypropylene beakers containing $40 \mathrm{~mL}$ test water. When the test terminated, sub-water samples were collected from each treatment for analysis of dissolved $\mathrm{Zn}$. The sub-samples were acidified to $\mathrm{pH} 2$ with saturated $\mathrm{HNO}_{3}$ (Merck) prior to analysis. Dissolved $\mathrm{Zn}$ analysis was performed by ICP-MS (as described above). The record of mortality and removal of dead organisms from the test beakers were performed daily. Mortality was the test end point and the data were used to determine median lethal concentrations $\left(\mathrm{LC}_{50}\right)$. Based on the $48 \mathrm{~h}-\mathrm{LC}_{50}$ values from the acute tests, the concentrations of 28,46 and $75 \mu \mathrm{g} \mathrm{Zn} / \mathrm{L}$ were chosen for the chronic exposures.

Chronic tests were performed according to the APHA (2005) and Dao et al. (2010) with minor modification on the temperature and light: dark cycle for tropical organisms. Briefly, neonates of $D$. lumholtzi less than $24 \mathrm{~h}$ from $2^{\text {nd }}-3^{\text {rd }}$ clutch were individually incubated in 50 $\mathrm{mL}$ polypropylene beaker containing $20 \mathrm{~mL}$ filtered river water. For each treatment (control or $\mathrm{Zn}$ exposure), 15 replicates were prepared. The food and test conditions were the same as the rearing conditions mentioned above. Media and food for daphnids were renewed 3 times per week. The life history traits of daphnids including the dead, maturation, reproduction were daily observed. The chronic tests lasted for 14 days. Water temperature (WTW Oxi197i multi-detector), dissolved oxygen (DO, WTW 350i), and pH (Metrohm 744) were measured at test initiation and termination (for acute test) or medium renewal (chronic test).

\subsection{Data Analysis}

Median lethal concentration with $95 \%$ confidence intervals (95\% CIs) was calculated by the Probit (USA). Shapiro-Wilk test (Sigma Plot, version 12) was applied for calculation of the significant difference of the maturation of D. lumholtzi in control and $\mathrm{Zn}$ exposures.

\section{Results}

\subsection{Physical and Chemical Characteristics of Field Water From Saigon River}

The ICP/MS analysis showed that filtered field water from Saigon River contained several metals with quite low concentrations $(2 \mu \mathrm{g} / \mathrm{L}$ of $\mathrm{Cu}, 5 \mu \mathrm{g} / \mathrm{L}$ of $\mathrm{Zn})$, except Al (111 $\mu \mathrm{g} / \mathrm{L}), \mathrm{Mn}$ $(43 \mu \mathrm{g} / \mathrm{L})$ and Fe $(279 \mu \mathrm{g} / \mathrm{L}$, Table 2$)$.

Table 2. Dissolved metal concentrations $(\mu \mathrm{g} / \mathrm{L})$ in filtered field water from Saigon River. BDL, below detection limits of the ICP/MS, $1 \mu \mathrm{g} / \mathrm{L}$.

\begin{tabular}{|l|l|l|l|l|l|l|l|l|l|}
\hline $\mathrm{Al}$ & $\mathrm{Ag}$ & $\mathrm{As}$ & $\mathrm{Au}$ & $\mathrm{Be}$ & $\mathrm{B}$ & $\mathrm{Ba}$ & $\mathrm{Co}$ & $\mathrm{Cr}$ & $\mathrm{Cu}$ \\
\hline 111 & $\mathrm{BDL}$ & $\mathrm{BDL}$ & $\mathrm{BDL}$ & $\mathrm{BDL}$ & $\mathrm{BDL}$ & $\mathrm{BDL}$ & $\mathrm{BDL}$ & $\mathrm{BDL}$ & 2 \\
\hline $\mathrm{Fe}$ & $\mathrm{Mn}$ & $\mathrm{Ni}$ & $\mathrm{Pb}$ & $\mathrm{Sr}$ & $\mathrm{Se}$ & $\mathrm{Sb}$ & $\mathrm{V}$ & $\mathrm{Ti}$ & $\mathrm{Zn}$ \\
\hline 279 & 43 & BDL & BDL & BDL & BDL & BDL & BDL & BDL & 5 \\
\hline
\end{tabular}




\section{Macrothink}

Environmental Management and Sustainable Development

ISSN 2164-7682

2016, Vol. 5, No. 2

The physical and chemical measurement showed that the $\mathrm{pH}$ and dissolved oxygen of field water from Saigon River was 7.07 and $6.2 \mathrm{mg} / \mathrm{L}$, respectively (Table 3). The $\mathrm{pH}$ in the test water (control and $\mathrm{Zn}$ exposures) slightly varied from $7.03-7.31$. The hardness and alkalinity of Saigon river water used for the tests were 29 and $15 \mathrm{mg} / \mathrm{L}$ (as $\mathrm{CaCO}_{3}$ ), respectively.

Table 3. Physical and chemical characteristics of the field water from Saigon River and the test water during the experiments.

\begin{tabular}{|l|l|}
\hline Parameters & Saigon River \\
\hline $\mathrm{pH}$ (in the field water) & 7.07 \\
\hline $\mathrm{pH}$ (in the test water after metal addition) & $7.07-7.31$ \\
\hline Dissolved oxygen in the test water $\left(\mathrm{mg} \mathrm{L}^{-1}\right)$ & 6.2 \\
\hline Hardness $\left(\mathrm{mg} / \mathrm{L}\right.$ as $\left.\mathrm{CaCO}_{3}\right)$ & 29 \\
\hline Alkalinity $\left(\mathrm{mg} / \mathrm{L}\right.$ as $\left.\mathrm{CaCO}_{3}\right)$ & 15 \\
\hline
\end{tabular}

\subsection{Acute and Chronic Effects of Zn on Daphnia Lumholtzi}

The result of acute test showed that the $48 \mathrm{~h}-\mathrm{LC}_{50}$ was $136 \mu \mathrm{g} \mathrm{Zn} / \mathrm{L}(95 \% \mathrm{CI}=107-165 \mu \mathrm{g}$ $\mathrm{Zn} / \mathrm{L}$ ). In chronic exposures, the survival proportion of D. lumholtzi in the control was $80 \%$ after 14 days of incubation while the survival rate of the animals in the exposures to 28 and $46 \mu \mathrm{g} \mathrm{Zn} / \mathrm{L}$ was 60 and 46\%, respectively (Fig. 3). However, the first D. lumholtzi in the exposure to $75 \mu \mathrm{g} \mathrm{Zn/L} \mathrm{started} \mathrm{to} \mathrm{die} \mathrm{after} 4$ days of incubation then the survival of the animals in this treatment sharply decreased afterward. The last D. lumholtzi died on the $9^{\text {th }}$ day of experiment (Fig. 3).

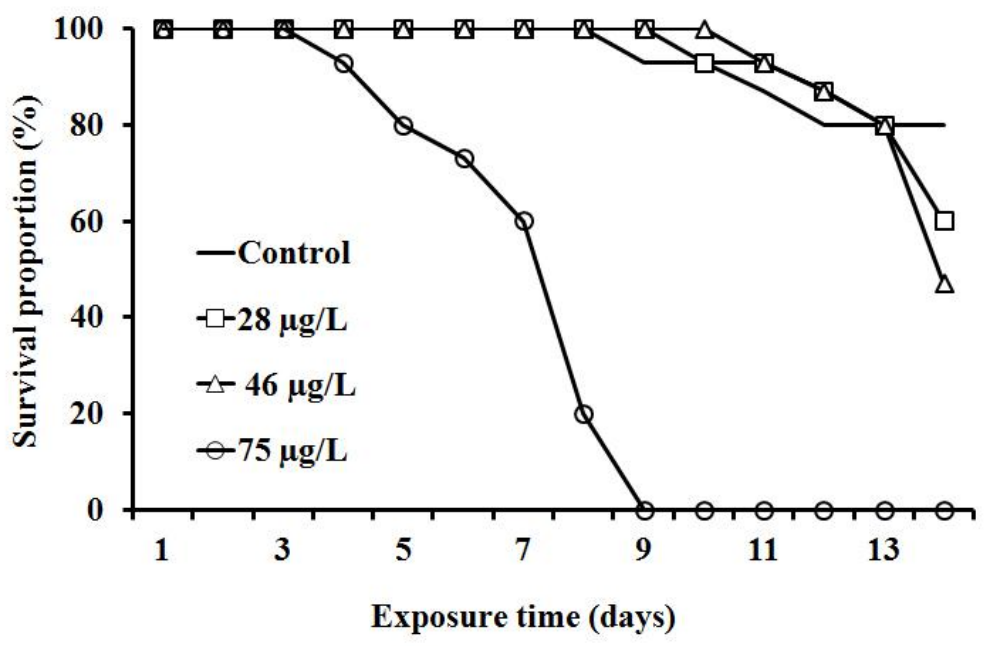

Figure 3. Survival proportion of Daphnia lumholtzi exposed to Zn spiked into filtered water from Saigon River

The maturation of $D$. lumholtzi from the chronic tests was showed in the Figure 4. The animals in the control and the two lower $\mathrm{Zn}$ concentration exposures reached their maturity age at approximately 3 days old. However, exposed the highest $\mathrm{Zn}$ concentration, $75 \mu \mathrm{g} / \mathrm{L}$, 


\section{Macrothink}

the D. lumholtzi matured at around 4 days old, significantly delayed its maturation compared to the control.

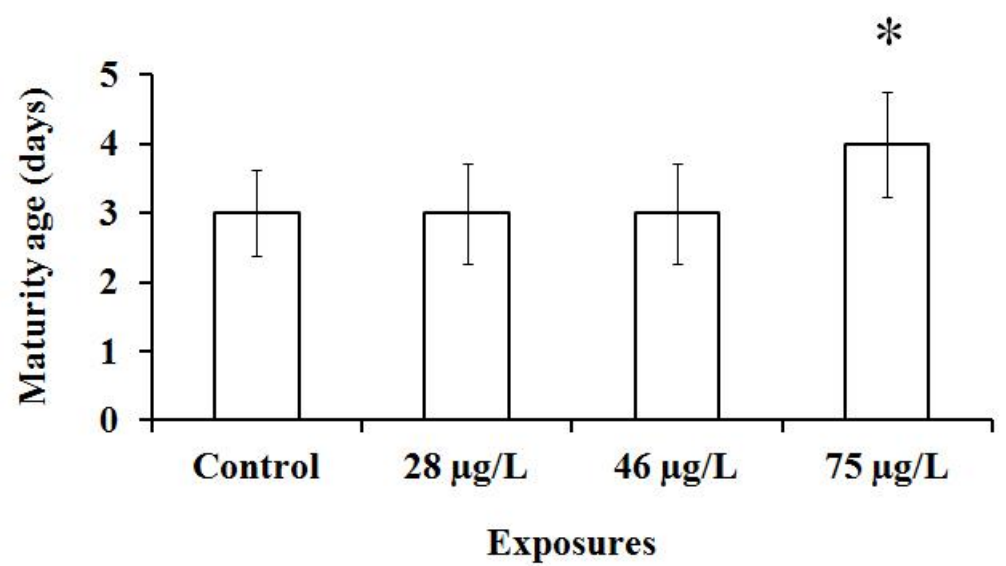

Figure 4. Maturity age of Daphnia lumholtzi (mean value \pm SD) exposed to Zn spiked into filtered water from Saigon River. Asterisk indicates significant difference between control and exposures by Shapiko-Wilk test $\left(^{*}, \mathrm{P}<0.01\right)$.

The accumulative neonates from the control were 329. However, those from the exposures to $\mathrm{Zn}$ at the concentrations of 28, 46 and $75 \mu \mathrm{g} / \mathrm{L}$ were 335, 279 and 38, respectively (Table 4).

Table 4. The total accumulated offspring Daphnia lumholtzi in the exposures during 14 days of experiment.

\begin{tabular}{|l|l|l|l|}
\hline Control & $28 \mu \mathrm{g} \mathrm{Zn} / \mathrm{L}$ & $46 \mu \mathrm{g} \mathrm{Zn} / \mathrm{L}$ & $75 \mu \mathrm{g} \mathrm{Zn} / \mathrm{L}$ \\
\hline 329 & 335 & 279 & 38 \\
\hline
\end{tabular}

\section{Discussion}

\section{Chemical and physical characteristics}

Generally, the trace metals of field water from Saigon River in the current study were quantitatively more or less similar to that from the same location in a previous investigation (Bui et al., 2016). Besides, the concentrations of some found trace metals (e.g. $\mathrm{Cu}, \mathrm{Zn}$ ) in Saigon River in our study were comparable to those from Mekong River (Dao et al., 2016). Hence, based on the metal characteristics the filtered water from Saigon River would be suitable for using as the control medium for testing with the micro-crustacean D. lumholtzi.

Both $\mathrm{pH}$ and DO in the test water were favorable for the living and growth of daphnids (APHA, 2005). The $\mathrm{pH}$ of water in this study was slightly higher than that from Saigon and Dongnai Rivers in a previous study (6.62 - 6.92; Bui et al., 2016), but similar to the $\mathrm{pH}$ range from Mekong River or many other tropical rivers and lakes (7.03 - 8.62; Villavicencio et al., 2005; Dao et al., 2016). The hardness and alkalinity from Saigon River used for the current study were not high and could be classified into the soft water as described in previous investigations (Villavicencio et al., 2005; Naddy et al., 2015). The soft water would enhance the toxicity of dissolved metal to daphnids. The $\mathrm{pH}$, alkalinity and hardness of the test water should regulate the toxicity of dissolved metals in our acute and chronic tests. 
Acute test

The 48h-LC50 value for $D$. lumholtzi exposed to $\mathrm{Zn}$ dissolved in Saigon River from this study water was lower than that in Mekong River (Dao et al., 2016). So toxicity of Zn became more potent in Saigon River compared to Mekong River water. The $\mathrm{pH}$, alkalinity and hardness of Saigon River water were lower than those of Mekong River water and that should be the major root of the two different acute test results of our study and investigation of Dao et al. (2016). This supports the report of De Schamphelaere and Janssen (2002) and Jo et al. (2010).

The values of 48h-LC ${ }_{50}$ of D. magna and Ceriodaphnia.dubia to Zn were 928 and $102-130$ $\mu \mathrm{g} / \mathrm{L}$, respectively (Naddy et al., 2015; Traudt et al., 2016) at moderately hard water (in the test with D. magna) and hard water (in the test with $C$. dubia) revealed that $D$. lumholtzi was more sensitive to $\mathrm{Zn}$ than D. magna but less sensitivity to $\mathrm{Zn}$ than C. dubia. This record is in line with previous investigation revealing the high sensitivity of $D$. lumholtzi to trace metals (Dao et al., 2016).

\section{Chronic test}

The high survival rate of $D$. lumholtzi in control (80\%) after 14 days of experiment met the requirement of APHA (2005). However, the much lower survival rate in the exposures to 28 and $46 \mu \mathrm{g} \mathrm{Zn/L} \mathrm{(Fig.} \mathrm{3)} \mathrm{supported} \mathrm{the} \mathrm{previous} \mathrm{study} \mathrm{in} \mathrm{which} \mathrm{D.} \mathrm{lumholtzi} \mathrm{was} \mathrm{incubated} \mathrm{in}$ Mekong River water containing $50 \mu \mathrm{g} \mathrm{Zn} / \mathrm{L}$ (Dao et al., 2016). Seriously the exposure to 75 $\mu \mathrm{g} \mathrm{Zn/L} \mathrm{caused} \mathrm{the} \mathrm{collapse} \mathrm{of} \mathrm{the} \mathrm{daphnid} \mathrm{population} \mathrm{within} 9$ days of treatment. The Vietnam Environmental Protection Agency issued the allowed $\mathrm{Zn}$ concentration in the industrial wastewater of $3000 \mu \mathrm{g} / \mathrm{L}$ (QCVN 40:2011) which is far higher than the test concentrations of $\mathrm{Zn}$ used in our study. Therefore, the Vietnam guideline values regarding $\mathrm{Zn}$ concentration in wastewater should be re-considered and adjusted to protect the aquatic organism in nature.

Acharya et al. (2006) raised D. lumholtzi in water from Ohio River and observed the age to first clutch of the animals of around 7 days old. The maturity age of $D$. lumholtzi incubated in field water from Saigon River of around 3 days old which is similar to study result with Mekong River water of Dao et al. (2016). Hence, the daphnids raised in Saigon River water seemed to reach its maturation a little earlier than those in Ohio River water. Ebert (1992) hypothesized that the maturation of daphnids is closely related to threshold size and the animals' maturation could only be initiated at a certain body size. Properly, the experiment conditions, food availability and quality could strongly regulate the development or growth consequently maturation of daphnids. The response of D. lumholtzi to $\mathrm{Zn}$ at the concentration of $75 \mu \mathrm{g} / \mathrm{L}$ in our study is in line with previous investigations in which $D$. lumholtzi exposed to $50-56 \mu \mathrm{g} \mathrm{Zn} / \mathrm{L}$ and $D$. obtusa shortly exposing to $\mathrm{Cr}$ delayed the maturation and time to first reproduction (Coniglio and Baudo, 1989; Dao et al., 2016).

Zinc at low concentrations should be an essential trace element for the living and growth of micro-crustacean (Kilham et al., 1998). However, the metals at high concentration could induce the impairment on the respiratory function of D. magna (Pane et al., 2003) and inhibit 
the sodium uptake leading to the osmotic imbalance in aquatic animals (Grosell et al., 2002) leading to the energy cost for maintain consequently fecundity reduction. This helped to explain the strong inhibition on reproduction in the exposure to 46 and $75 \mu \mathrm{g} \mathrm{Zn/L} \mathrm{(Table} \mathrm{4)}$ which was ever reported elsewhere (Dao et al., 2016).

\section{Conclusions}

Saigon River water, at the time of sampling, had a sufficient quality regarding metals contamination for growth and development of micro-crustaceans. The effect of $\mathrm{Zn}$ on survival of $D$. lumholtzi in acute and chronic test revealed the high sensitive of this animal to $\mathrm{Zn}$. Chronic exposures caused the maturity postponement and reproduction inhibition of the D. lumholtzi. The results of this study are confident proofs for the reconsideration and adjustment of the Vietnam guideline values related to $\mathrm{Zn}$ concentration in wastewater for the aquatic ecosystem protection. The negative effects of $\mathrm{Zn}$ on $D$. lumholtzi may be useful for extrapolation/ prediction the potential toxicity of the trace metal to micro-crustaceans in situ in the future. Further investigations on the toxicity of $\mathrm{Zn}$ to other tropical organisms and combined effects of $\mathrm{Zn}$ and other pollutants in river water on $D$. lumholtzi are suggested.

\section{Acknowledgement}

This study was funded by the Vietnam National University - Hochiminh City under the granted project number B2014-48-01.

\section{References}

Achary, K., Jack, J. D., \& Smith, A. S. (2006). Stoichiometry of Daphnia lumholtzi and their invasive success: Are they linked? Archiv für Hydrobiologie 165, 433-453. http://dx.doi.org/10.1127/0003-9136/2006/0165-0433.

American Public Health Association (APHA). (2005). Standard methods for the examination of water and wastewater. Washington $D C$.

Biesinger, K. E., \& Christensen, G. M. (1972). Effects of various metals on survival, growth, reproduction, and metabolism of Daphnia magna. Canadian Journal of Fisheries Research Board, 29, 1691-1700. http://dx.doi.org/10.1139/f72-269.

Bui, T. K. L., Do-Hong, L. C., Dao, T. S., \& Hoang, T. C. (2016). Copper toxicity and the influence of water quality of Dongnai River and Mekong River waters on copper bioavailability and toxicity to three tropical species. Chemosphere, 144, 872-878. http://dx.doi.org/10.1016/j.chemosphere.2015.09.058.

Chanpiwat, P., \& Sthiannopkao, S. (2014). Status of metal levels and their potential sources of contamination in Southeast Asian rivers. Environmental Science and Pollution Research, 21, 220-233. http://dx.doi.org/10.1007/s11356-013-1858-8.

Chishty, N., Tripathi, A., \& Sharma, M. (2012). Evaluation of acute toxicity of zinc, lead and cadmium to zooplanktonic community in upper Berach river system, Rajasthan, India. South Asian Journal of Experimental Biology, 2(1), 20-25. 
Coniglio, L., \& Baudo, R. (1989). Life-tables of Daphnia obtusa (Kutz.) surviving exposure to toxic concentration of chromium. Hydrobiologia, 188/189, 407-410.

Dao, T. S., Do-Hong, L. C., \& Wiegand, C. (2010). Chronic effects of cyanobacterial toxins on Daphnia magna and their offspring. Toxicon, 55, 1244-1254. http://dx.doi.org/10.1016/j.toxicon.2010.01.014.

Dao, T. S., Le, V. N., Bui, B. T., Dinh, K. V., Wiegand, C., Nguyen, T. S., Dao, C. T., Nguyen, V. D., To, T. H., Nguyen, L. S. P., Vo, T. G., \& Vo, T. M. C. (2016). Sensitivity of a tropical micro-crustacean (Daphnia lumholtzi) to trace metals tested in natural water of the Mekong River. Science of the Total Environment (accepted manuscript). http://dx.doi.org/10.1016/j.scitotenv.2016.08.049.

Dave, G. (1984). Effects of copper on growth, reproduction, survival and haemoglobin in Daphnia magna. Comparative Biochemistry and Physiology, 78C(2), 439-443. http://dx.doi.org/10.1016/0742-8413(84)90112-9.

De Schamphelaere, K. A. C., \& Janssen, C. (2002). A biotic ligand model predicting acute copper toxicity for Daphnia magna: the effects of calcium, magnesium, sodium, potassium and pH. Environmental Science and Technology, 36, 49-54. http://dx.doi.org/10.1021/es000253s.

Do-Hong, L. C., Becker-van Slooten, K., Sauvain, J. J., Minh, T. L., \& Tarradellas, J. (2000). Toxicity of sediments from the Ho Chi Minh City canals and Saigon River, Vietnam. Environmental Toxicology, $15, \quad 469-475$. http://dx.doi.org/10.1002/1522-7278(2000)15:5<469::AID-TOX15>3.0.CO;2-0.

Ebert, D. (1992). A food-independent maturation threshold and size at maturity in Daphnia magna. Limnology and Oceanography, 37, 878-881. http://dx.doi.org/10.4319/1o.1992.37.4.0878.

Grosell, M., Nielsen, C., \& Bianchini, A. (2002). Sodium turnover rate determines sensitivity to acute copper and silver exposure in freshwater animals. Comparative Biochemistry and Physiology Part C, 133, 287-303. http://dx.doi.org/10.1016/s1532-0456(02)00085-6.

Jo, H. J., Son, J., Cho, K., \& Jung J. (2010). Combined effects of water quality parameters on mixture toxicity and chromium toward Daphnia magna. Chemosphere, 81, 1301-1307. http://dx.doi.org/10.1016/j.chemosphere.2010.08.037.

Kilham, S. S., Kreeger, D. A., Lynn, S. G., Goulden, C. E., \& Herrera, L. (1998). COMBO: a defined freshwater culture medium for algae and zooplankton. Hydrobiologia, 377, 147-159. http://dx.doi.org/10.1023/A:1003231628456.

Lampert, W. (2006). Daphnia: model herbivore, predator and prey. Polish Journal of Ecology $54,607-620$.

Munzinger, A. (1994). The influence of nickel on population dynamics and on some demographic parameters of Daphnia magna. Hydrobiologia, 277, 107-120. http://dx.doi.org/10.1007/BF00016758. 
Muyssen, B. T. A., De Schamphelaere K. A. C., \& Janssen, C. R. (2006). Mechanisms of chronic waterborne $\mathrm{Zn}$ toxicity in Daphnia magna. Aquatic Toxicology, 77, 393-401. http://dx.doi.org/10.1016/j.aquatox.2006.01.006.

Naddy, R. B., Cohen, A. S., \& Stubblefield, W. A. (2015). The interactive toxicity of cadmium, copper, and zinc to Ceriodaphnia dubia and rainbow trout (Oncorhynchus mykiss). Environmental Toxicology and Chemistry, 34, 809-815. http://dx.doi.org/10.1002/etc.2870.

Pane, E. F., Smith, C., McGeer, J. C., \& Wood, C. M. (2003). Mechanisms of acute and chronic waterborne nickel toxicity in the freshwater cladoceran, Daphnia magna. Environmental Science and Technology, 37, 4382-4389. http://dx.doi.org/10.1021/es0343171.

Paulauskis, J. D., \& Winner, R. W. (1988). Effects of water hardness and humic acid on zinc toxicity to Daphnia magna Straus. Aquatic Toxicology, 12, 273-290. http://dx.doi.org/10.1016/0166-445X(88)90027-6.

QCVN 40:2011 (2011). National technical regulation on surface water quality for protection of aquatic lifes (in Vietnamese). Ministry of natural Resources and Environment (Vietnam), 7pp.

Shaw, J. R., Pfrender, M. E., Eads, B. D., Klaper, R., Callaghan, A., Sibly, R. M., Colson, I., Jansen, B., Gilbert, D., \& Colbourne, J. K. (2008). Daphnia as an emerging model for toxicological genomics. Advances in Experimental Biology, 2, 165-219. http://dx.doi.org/10.1016/S1872-2423(08)00005-7.

Taylor, N. S., Kirwan, J. A., Johnson, C., Yan, N. D., VIant, M. R., Gunn, J. M., \& McGeer, J. C. (2016). Predicting chronic copper and nickel reproductive toxicity to Daphnia pulex-pulicaria from whole animal metabolic profiles. Environmental Pollution, 212, 325-329. http://dx.doi.org/10.1016/j.envpol.2016.01.074.

Tomasik, P., \& Warren, D. M. (1996). The use of Daphnia in studies of metal pollution of aquatic system. Environmental Reviews, 4, 25-64. http://dx.doi.org/10.1139/a96-003.

Traudt, E. M., Ranville, J. F., Smith, S. A., \& Meyer, J. S. (2016). A test of the additivity of acute toxicity of binary-metal mixtures of $\mathrm{Ni}$ with $\mathrm{Cd}, \mathrm{Cu}$ and $\mathrm{Zn}$ to Daphnia magna, using the inflection point of the concentration-response curves. Environmental Toxicology and Chemistry, accepted manuscript. http://dx.doi.org/10.1002/ect.3342.

US Environmental Protection Agency (US. EPA). (2002). Methods for measuring the acute toxicity of Effluents and Receiving Waters to Freshwater and marine organisms, $5^{\text {th }}$ ed. EPA-821-R02-012. Office of water, Washington, DC.

Vardia, H. K., Rao, P. S., \& Durve, V. S. (1988). Effects of copper, cadmium and zinc on fish-food organisms, Daphnia lumholtzi and Cypris subglobosa. Proc. Indian Acad. Sci. (Anim. Sci.), 97(2), 175-180. http://dx.doi.org/10.1007/BF03179945.

Villavicencio, G., Urrestarazu, P., Carvajal, C., De Schamphelaere, K. A. C., Janssen, C., Torres, J. C., \& Rodriguez, P. H. (2005). Biotic ligand model prediction of copper toxicity to daphnids in a range of natural waters in Chile. Environmental Toxicology and Chemistry, 24, 1287-1299. http://dx.doi.org/10.1897/04-095R.1. 


\section{Macrothink}

Environmental Management and Sustainable Development

ISSN 2164-7682

2016, Vol. 5, No. 2

Wetzel, R., G. (2001). Limnology - lake and river ecosystems. Academic Press, 305-310.

Winner, R. W., \& Farrell, M. P. (1976). Acute and chronic toxicity of copper to four species of Daphnia. Canadian Journal of Fisheries Research Board, 33, 1685-1691.

Wong, C. K. (1992). Effects of chromium, copper, nickel, and zinc on survival and feeding of the Cladocera. Bulletin on Environmental Contamination and Toxicology, 49, 593-399.

\section{Copyright Disclaimer}

Copyright for this article is retained by the author(s), with first publication rights granted to the journal.

This is an open-access article distributed under the terms and conditions of the Creative Commons Attribution license (http://creativecommons.org/licenses/by/3.0/). 